Gut, 1960, 1, 140.

\title{
LEUCINE AMINOPEPTIDASE WITH SPECIAL REFERENCE TO ULCERATIVE COLITIS
}

\author{
BY \\ L. J. WITTS and S. W. PERRY \\ From the Nuffield Department of Clinical Medicine, Radcliffe Infirmary, Oxford
}

\begin{abstract}
It has been suggested that ulcerative colitis might be associated with excessive production of histamine released locally from mast cells. These cells also contain a proteolytic enzyme, leucine aminopeptidase, which might also be released at the same time if this hypothesis were correct. The studies reported do not invalidate this concept of aetiology in ulcerative colitis but provide no positive evidence in support of it.
\end{abstract}

Leucine aminopeptidase is a proteolytic enzyme which is capable of hydrolysing L-leucyl peptides and is widely distributed throughout the body. The level of this enzyme in the serum is usually much raised in obstructive jaundice from cancer of the pancreas but this reaction is not constant and aminopeptidase is elevated to a lesser extent in other forms of jaundice. Moreover, very high values are normally found in the third trimester of pregnancy (Rutenburg, Goldbarg, and Pineda, 1958; Arst, Manning, and Delp, 1959; Bressler and Forsyth, 1959).

The tissue mast cells give a histochemical reaction for leucine aminopeptidase. When tissues containing many mast cells are exposed to hypotonic solutions in vitro, the mast cells rupture and there is an increase of aminopeptidase in the surrounding fluid. The human skin in urticaria pigmentosa is infiltrated with mast cells and friction of the affected areas may produce an increase of leucine aminopeptidase in the serum (Braun-Falco and Salfeld, 1959).

The mast cells contain other important constituents besides aminopeptidase, in particular heparin, histamine, and 5-hydroxytryptamine. A number of pharmacological agents are known which cause histamine to be released within the organism and all of these cause swelling, degranulation, and even disruption of the mast cells (Riley, 1959). Mast cells are increased in the tissues in chronic inflammation, and McGovern (1956) suggested that the permeability of serous membranes might be related to their activity. Subsequently, McGovern and Archer (1957) discussed the pathogenesis of ulcerative colitis in terms of histamine-release phenomena. They suggested that augmented barrages of nervous impulses during stress might give rise to excessive production of acetylcholine in the colon, which would then react with the tissue mast cells causing release of histamine. "We felt that if this hypothesis were correct, aminopeptidase should also be released and might be detected in the blood stream. With this objective in view we have estimated leucine aminopeptidase in the serum in ulcerative colitis and other conditions.

\section{METHODS}

The method of Goldbarg and Rutenburg (1958) was used. This depends on the enzymatic hydrolysis of L-leucyl- $\beta$-naphthylamide hydrochloride and the estimation of the $\beta$-naphthylamine released by a modification of the Bratton-Marshall reaction. It was found that the final colour reaction was photosensitive and estimations were therefore carried out in a darkened laboratory. The results were expressed in units, each unit being equivalent to $1 \mu \mathrm{g}$. of $\beta$-naphthylamine liberated from $200 \mu \mathrm{g}$. of L-leucyl- $\beta$-naphthylamide after incubation with $1 \mathrm{ml}$. of $2 \%$ serum for two hours at $37^{\circ} \mathrm{C}$. These units should be multiplied by 12 if it is desired to convert them to the arbitrary units used by Goldbarg and Rutenburg (1958). Our unit is also different from that used by Arst et al. (1959), whose mean normal value for serum was 100 units.

\section{RESULTS}

Leucine aminopeptidase was estimated in the serum of normal persons and patients with ulcerative colitis, jaundice, and other diseases. Normal levels averaged 16 units, with a range of 10 to 31 units. Levels in 31 patients with ulcerative colitis were normal, the mean being 19 and the range 11 to 34 units. High levels were found only in patients with jaundice. The highest levels were in jaundice 
TABLE

SERUM LEUCINE AMINOPEPTIDASE ACTIVITY IN VARIOUS CONDITIONS

\begin{tabular}{|c|c|c|c|c|}
\hline & No. & Range & Mean & S.D \\
\hline $\begin{array}{l}\text { Normals } \\
\text { Ulcerative colitis } \\
\text { Various diseases including leukaemia } \\
\text { Jaundice }\end{array}$ & $\begin{array}{l}19 \\
31 \\
25\end{array}$ & $\begin{array}{r}10-31 \\
11-34 \\
9-37\end{array}$ & $\begin{array}{l}16 \\
19 \\
22\end{array}$ & $\begin{array}{l}5 \\
9 \\
7\end{array}$ \\
\hline $\begin{array}{l}\text { Infective hepatitis } \\
\text { Weil's disease } \\
\text { Non-malignant obstructive jaundice } \\
\text { Carcinoma of pancreas } \\
\text { Carcinoma of gall-bladder }\end{array}$ & $\begin{array}{l}2 \\
1 \\
9 \\
7 \\
1\end{array}$ & $\begin{array}{l}20-32 \\
21-60 \\
32-78\end{array}$ & $\begin{array}{l}26 \\
38 \\
36 \\
51 \\
77\end{array}$ & $\begin{array}{l}\text { 二 } \\
\text { 二 }\end{array}$ \\
\hline
\end{tabular}

due to malignant disease but a high value of 60 units was noted in a patient with non-malignant obstructive jaundice. This was a post-operative estimation and Goldbarg and Rutenburg (1958) have observed a post-operative rise in serum leucine aminopeptidase.

In view of the normal findings in ulcerative colitis, it was decided to see if the serum aminopeptidase was, in fact, increased in experimental animals after the phenomenon of histamine release. The mean level in 30 normal rats was 14 , with a range of 11 to 18 units. Eight rats were given an intraperitoneal injection of $100 \mu \mathrm{g}$. of the histamine liberator, compound $48 / 80$, and the serum aminopeptidase was estimated at intervals during the subsequent two-and-a-quarter hours. A few minutes after the injection the animals showed signs of shock with cyanosis of the ears. There was no change in serum aminopeptidase activity.

\begin{tabular}{c|c|c}
\hline $\begin{array}{c}\text { Time } \\
\text { (min.) }\end{array}$ & $\begin{array}{c}\text { No. of } \\
\text { Estimations }\end{array}$ & $\begin{array}{c}\text { Mean } \\
\text { Value }\end{array}$ \\
\hline 0 & 4 & 14 \\
5 & 2 & 14 \\
15 & 2 & 12 \\
45 & 2 & 11 \\
135 & 2 & 10 \\
\hline
\end{tabular}

In a subsequent experiment $300 \mu \mathrm{g}$. compound $48 / 80$ was injected intraperitoneally in rats and estimations were carried out at intervals during the subsequent 24 hours. Again there was no change in the serum aminopeptidase.

\begin{tabular}{c|c|c}
\hline $\begin{array}{c}\text { Time } \\
\text { (hr.) }\end{array}$ & $\begin{array}{c}\text { No. of } \\
\text { Estimations }\end{array}$ & Result \\
\hline 0 & 1 & 14 \\
1 & 1 & 15 \\
2 & 1 & 12 \\
4 & 1 & 11 \\
8 & 1 & 12 \\
24 & 16 \\
\hline
\end{tabular}

\section{Discussion}

Our experiments have confirmed the reports of other workers that leucine aminopeptidase is increased in the serum of patients with obstructive jaundice, particularly when this is due to carcinoma. We have found no increase in chronic ulcerative colitis. This result does not necessarily invalidate the hypothesis of McGovern and Archer (1957) that ulcerative colitis may be a histamine-release phenomenon, associated with discharge of the contents of the mast cells in the colon, for, although heparin and leucine aminopeptidase should be simultaneously released, it does not follow that they will pass into the blood stream. Previous workers have shown that there is no rise of heparin in the blood of the rat after the injection of histamine liberators and we have shown that there is likewise no increase in leucine aminopeptidase. It therefore seems probable that further testing in man of McGovern and Archer's hypothesis will have to be made on specimens from the affected colon itself.

We are indebted to Dr. A. C. White of the Wellcome Research Laboratories for a supply of $48 / 80$ histamine liberator.

\section{REFERENCES}

Arst, H. E., Manning, R. T., and Delp, M. (1959). Amer. J. med. Sci., 238, 598.

Braun-Falco, O and Salfeld, K. (1959). Nature (Lond.), 183, 51. Bressler, R., and Forsyth, B. R. (1959). New Engl. J. Med., 261, 746. Goldbarg, J. A., and Rutenburg, A. M. (1958). Cancer (Philad.), 11, 283.

McGovern, V. J. (1956). J. Path. Bact., 71, 1.

Mc and Archer, G. T. (1957). Aust. Ann. Med., 6, 68.

Riley, J. F. (1959). The Mast Cells. Livingstone, Edinburgh and

London.
Rutenburg, A. M., Goldbarg, J. A., and Pineda, E. P. (1958). New Engl. J. Med., 259, 469. 